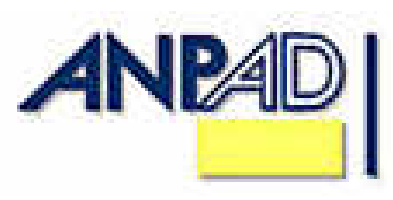

Available online at

http://www.anpad.org.br/bar

\title{
The Competence Accumulation Process in the Technology Transference Strategy
}

\author{
André Silva de Souza * \\ E-mail address: a_s_souza@yahoo.com.br \\ KNAPP Sudamérica Ltda. \\ Curitiba, PR, Brazil.
}

\section{Andréa Paula Segatto-Mendes}

E-mail address: apsm@ufpr.br

Centro de Pesquisa e Pós-Graduação em Administração - Universidade Federal do Paraná

Curitiba, PR, Brazil.

\begin{abstract}
The present article evaluates and measures the technological competence accumulation in an automation area enterprise to distribution centers, Knapp Sudamérica Logistic and Automation Ltd, in the interval of the technology transference process previous period (1998-2001) and during the technology transference process (2002-2005). Therefore, based on an individual case study, the study identified the technology transference strategy and mechanism accorded between the head office and the branch office, the technological functions and activities developed by the receiver and, at last, the critical factors present in this process. The technological competences accumulation exam was accomplished based on an analytical structure existent in the literature that was adapted to the researched segment analysis. The obtained results showed that the planed, organized, controlled and continuous effort to generating and disseminating knowledge allowed the enterprise to speed up the accumulation process of technological competences promoting the converting of this process from individual level to the organizational one: besides, it also allowed the identification of barriers and facilitators involved in this process.
\end{abstract}

Key words: technology; technology transfer; technological ability; processes and mechanisms of learning.

Received in 22 January 2008; received in revised form 02 April 2008.

Copyright (C) 2008 Brazilian Administration Review. All rights reserved, including rights for translation. Parts of this work may be quoted without prior knowledge on the condition that the source is identified.

*Corresponding author: André Silva de Souza

Rua Paulino de Siqueira Cortes, 2600, apto. 304, São José dos Pinhais, Curitiba, PR, 83005-030, Brazil. 


\section{INTRODUCTION}

To acknowledge that technology has become a precious, and who knows, the most valuable resource to the organizations that aim reach competitive levels claimed by the society sectors, is not new (Gibbons \& Limoges, 1994; Katz, 1995; Pavitt, 1985, 1998; Rothwell \& Dodgson, 1991). It is already self-evident true to assert that it became a primordial strategic resource to the enterprises which make use of this way to keep competitive.

Its transference, by its time, constitutes a complex phenomenon that involves different functions, agents and variable factors, forming a process that is not reducible to simple factors, that involves technical, economical and social changes, once they affect not only engineering activities, but also several sides of managing and organization activities (Saad, 2000).

According to Saad (2000), its success is rarely associated to the execution of one or two points that detaches, but through the developing of all functions in effective and integrated way. The technology transference process study has detached the importance of the implementing phase that is seen as a dynamic process of mutual adapting between technology and its new environment, falling to the receiver being endowed with enough technological competences to incorporate this innovation (Figueiredo, 2003).

In this study technological competence will be defined as the need resources to obtain and manage improvements in terms of production, products, equipments and engineering projects processes and organization. Such resources accumulate and incorporate in individuals and organizational systems (Bell \& Pavitt, 1995).

The theme approached is the head-branch office technology transference and, more specifically, it is intended to verify how this technological competence accumulation happened in an enterprise (branch) which has undergone this process.

\section{MeChanisms AND Strategies to TeCHNOlOGy TRANSFERENCE}

The technology transference process complexity depends on several channels or mechanisms through which it can occur. This complexity is amplified by the fact that neither the process itself nor the pack to be transferred happens in a homogeneous way. It can be transferred through a complete "pack", or fragmented in small "packs" (Saad, 2000).

According to Saad (2000) the transference can happen through distinct channels or mechanisms that include licensing, franchising, sub contracting, and the turnkey plants sale.

Licensing accomplishes a variety of contract arrangements through which an organization (owner) sells an intangible patrimony or the propriety rights (patents, industrial secrets, know-how, registered mark, and the company name) to an enterprise (receiver). These transference or intangibles or propriety rights constitute the essence of a licensing agreement. Upon this agreement, the receiver enterprise supplies a limited range of rights to produce and merchandise the licensed object in specific geographical regions.

The main advantage of licensing is the possibility that of the receiver organization has of getting a good financial gain, without the need of high expenses with marketing or investments in the form of production, making it possible its insertion in new markets. On the other hand, the biggest disadvantage of the product holder is the risk of losing control, once he does not own the effective forms of controlling manufacturing, marketing and distribution (Saad, 2000). 
Licensing may not allow the receiver organizations to get its technology reaching market quicker and launch the new product without the risk of spending heavily in activities of P\&D. This form of agreement if frequently associated to high costs, long negotiations and excessive adaptation and preparing before being apt to use the licensed technology.

Franchising is a licensing variation in which an enterprise (franchising holder) licenses an entire business system as well as offers property rights to a receiver organization, possibly established in a developing country (franchising receiver). The franchising receiver organizes its business under franchising holder's brand name and hopes that the proceedings and established norms are followed by the franchising holder. This agreement form propitiates the holder an effective way to quick expansion and new markets, especially, foreigners. However, this can mean losing control upon the receiver activities. To the receiver, in most cases, this way of technology transference does not promote significant technological capabilities and ability development (Saad, 2000).

The sub-contracting, a mechanism also known as third part agreement, happens when an organization (head office) establishes an order with other organization (third part branch) to manufacture parts, components and anatomical pieces that are incorporated to the product the head office enterprise will merchandise (United Nations Industrial Development Organization [UNIDO], 2002). This covers since purchasing agreements of components till the whole production of a specific product. Through this form of agreement, developed country enterprises can enter new markets of developing countries without making use of significant financial and management resources, and without losing control of their the market activities.

It can be seen that technology can be transferred in several ways and can take position in both directions, for the contractor as well as the third part. For instance, a turnkey project, the develop technology is furnished (by the contracted part), built and installed with capital investments in equipment, with the intention of altering the control and operation to enterprises of developing countries, after a time period of the agreement. The technology furnisher (head office) does not have, however, the control on distribution and sale, once the agreed period in contract is expired. This kind of contract is important to industries transference, involving the complex technologies acquisition and building up a large scale of capital works. However, when local handwork is not able or available, this kind of technology transference gives place to problems such as: operation, repairing, maintenance and part changing (Saad, 2000).

Other kinds of technology transference include joint ventures, cooperative researches agreements and co-production agreements; high technology and improvement products exportation, engineering, scientific and technological knowledge professional exchange, scientific and technological conferences, training, business visits, literature opening such as newspapers, magazines, books and issues, industrial spying, and governmental assistance programs (Organisation for Economic CoOperation and Development, 1994).

The strategies to the technology transference process accomplishing used by the majority of the developing countries are summarized, by this work, in three categories or models: hardware, software, and capital model (direct foreign investment) (Saad, 2000).

The hardware model does not normally generate significant technology capability absorption and is based in purchasing and acquisition of a complete system of equipments, such as machinery. This model can promote a significant speeding up of technological improvement especially during the technology transference process beginning, on the other hand the acquisition is essentially promoted by means of a pack of contracts that can take the receiver to a passive position during all the process.

With the software model, the process emphasis is placed in transference and acquisition of information and knowledge allowing the receiver to use, adept and manages the technology. This strategy can lead to acquisition of knowledge and abilities, enhancing innate capabilities, but it takes years for this strategy and requires the receiver involvement and the adoption of contracts that aim clarifying by means of proceedings, manuals, enough instruction to the new technology acquirement. 
The capital model target is to acquire, by means of direct foreign investments, technology and capabilities of international market access and usage. They can promote the access to a complete set if advanced technologies, business and managing techniques so that the acquisition execution of new technology depends mostly on the offered incentives by outer investors, as well as on the evaluation of innate capabilities of absorption, technological capabilities, transference mechanisms and agreed policies.

\section{ACCUMULATION OF TECHNOLOGICAL COMPETENCES: CONSTRUCTION OF A TECHNOLOGICAL COMPETENCE ACCUMULATION TRAJECTORY DESCRIPTIVE MODEL}

The technological competence can be understood as needed resources to generate and manage the technological changes, such us aptitudes, knowledge and experience and organizational systems (Bell \& Pavitt, 1993, 1995). More specifically technological competence is due to the enterprise abilities to promote inner improvement in different technological functions, for instance, organization and control processes, engineering activities and projects managing, activities related to production and equipments. It gives rise to a dissociation of different technological competence types, to the developed model manner of Figueiredo (2003). Such model makes the distinction between routine technological competences and innovative technological competences. The routine competences are related to technological activities taken part in a determined level of efficiency and input usage, they are the necessary capabilities to the usage of technologies, knowledge and organizational mechanisms. By its side, the innovative competences allow creating, modifying or improving products and process; they are the necessary capabilities to modify technologies, knowledge, experience and organizational mechanisms.

The routine technological competences are understood according to Ariffin and Figueiredo (2003) classifying, and it is understood as the capability of producing goods and services in certain efficiency levels and certain input requirements; it can be defined as competences, knowledge and organizational arrangements linked to the usage of the existent technology. They are divided in basic level (1), renewed level (2), extra-basic level (3), pre-intermediate competence level (4), intermediate competence level (5) and advanced competence level (6).

1. Basic level: it is the initial level of technological competences. It represents the needed basic competences to the performing of a plant or fittings.

2. Renewed level: The organization increases the efficient in performing of plant or fittings, getting to create some routines to execute the activities.

3. Extra-basic competence level: in this level the enterprise begins small and intermittent adaptations in activities related to engineering and projects managing with the aim of amplifying its productive capabilities, with the possibility of creating some proceedings, norms and patterns to processes that are under its domain. On the other hand, the innovative technology competences are classified in three levels from pre-intermediate (4) to advanced (6) level, and they are defined as the capability of creating, modifying and improving products, processes and the production organization.

4. Pre-Intermediate competence level: in this level the enterprises begins to manipulate processes parameters, as for instance, quality indicators.

5. Intermediate competence level: in this level the enterprise begins the innovation processes based on research activities applied in engineering usage.

6. Advanced competence level: the enterprise presents production organization of high level coping with standards adopted in certifying organisms and worldwide class entity, with development of innovative products with the rationalizing of its processes via projects engineering and $\mathrm{P} \& \mathrm{D}$ (planning and development). 
Table 1: Descriptive and Analytical Structure for Levels Technological Capability

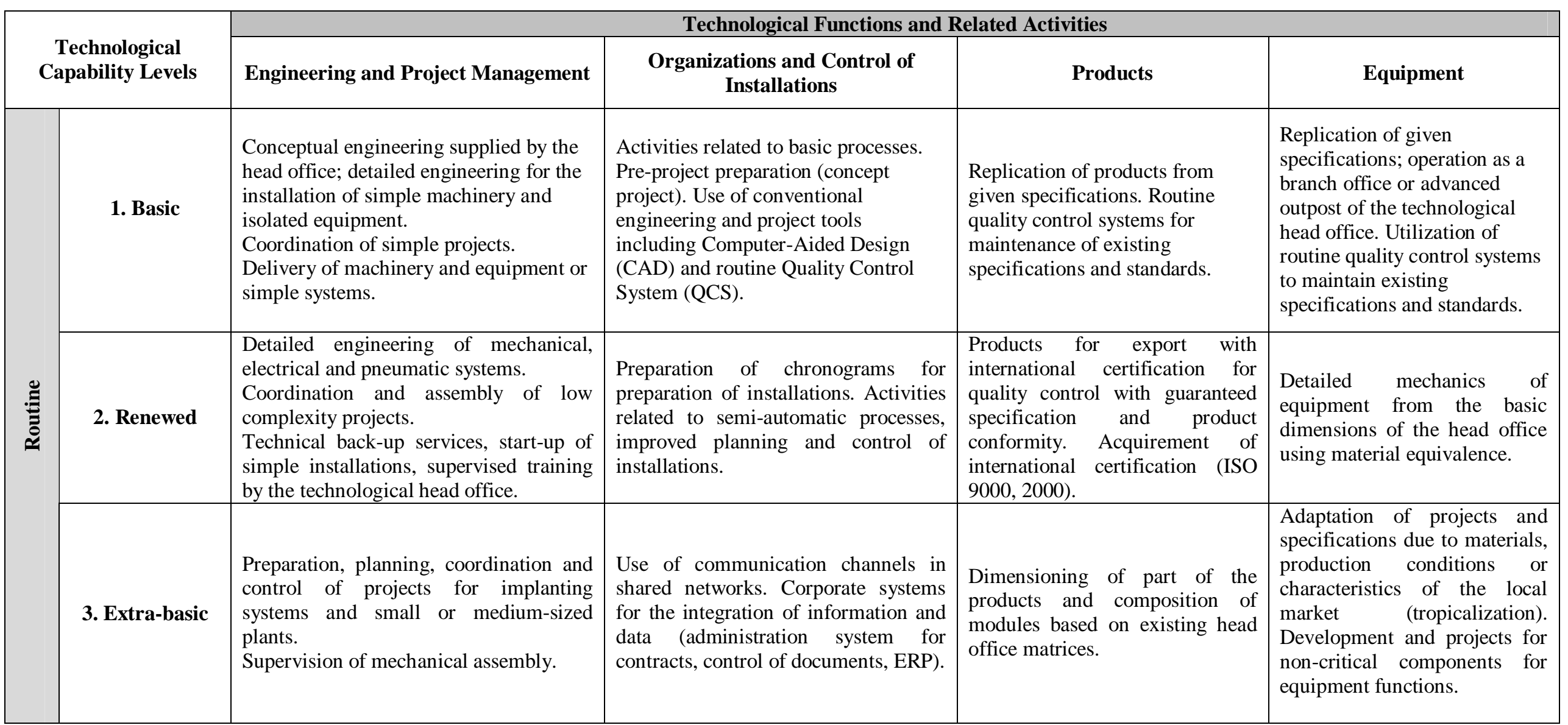




\section{(conclusion)}

Table 1: Descriptive and Analytical Structure for Levels Technological Capability

\begin{tabular}{|c|c|c|c|c|c|}
\hline \multirow{2}{*}{\multicolumn{2}{|c|}{$\begin{array}{c}\text { Technological } \\
\text { Capability Levels }\end{array}$}} & \multicolumn{4}{|c|}{ Technological Functions and Related Activities } \\
\hline & & Engineering and Project Management & $\begin{array}{c}\text { Organizations and Control of } \\
\text { Installations }\end{array}$ & Products & Equipment \\
\hline \multirow{3}{*}{ 葛 } & $\begin{array}{l}\text { 4. Pre- } \\
\text { intermediate }\end{array}$ & $\begin{array}{l}\text { Mid-level complexity project } \\
\text { management involving mechanical, } \\
\text { electric, pneumatic systems and detailed } \\
\text { engineering for acquisition (purchase, } \\
\text { inspection, qualification and } \\
\text { development of suppliers). Supervision } \\
\text { of mechanical and electric assembly. }\end{array}$ & $\begin{array}{l}\text { New organizational techniques: } \\
\text { strategic quality management (e.g. } \\
\text { TQC, ISO 9000:2000). } \\
\text { Development and use of advanced } \\
\text { tools linked to databases for project } \\
\text { engineering (MS-Project). }\end{array}$ & $\begin{array}{l}\text { Design and own development of } \\
\text { products through technological } \\
\text { assimilation from licensing } \\
\text { contracts and through } \\
\text { subcontracting of suppliers for } \\
\text { product production. }\end{array}$ & $\begin{array}{l}\text { Systematic improvement of } \\
\text { equipment and given } \\
\text { specifications. Project for } \\
\text { critical components and } \\
\text { machine parts and equipment. }\end{array}$ \\
\hline & 5. Intermediate & $\begin{array}{l}\text { Development of innovative solutions in } \\
\text { engineering involving installations } \\
\text { projects. } \\
\text { Application and execution of conceptual } \\
\text { engineering (project definitions, } \\
\text { laboratory tests and performance } \\
\text { simulations). } \\
\text { Implantation of large scale projects with } \\
\text { a high degree of complexity. } \\
\text { Local technical assistance for national } \\
\text { and international plants. }\end{array}$ & $\begin{array}{l}\text { Advanced systems for project } \\
\text { management with integration of } \\
\text { operational and corporate systems } \\
\text { (e.g. ISO-Project,). Development of } \\
\text { advanced engineering tools. }\end{array}$ & $\begin{array}{l}\text { Development of new products in } \\
\text { collaboration with head office, } \\
\text { suppliers and/or clients. } \\
\text { Development and selection of } \\
\text { new products. }\end{array}$ & $\begin{array}{l}\text { Development of new } \\
\text { equipment in collaboration } \\
\text { with head office and/or clients. } \\
\text { Development and selection of } \\
\text { new materials and equipment. }\end{array}$ \\
\hline & 6. Advanced & $\begin{array}{l}\text { Project management on a worldwide } \\
\text { scale, start up and pilot production test } \\
\text { for integrated systems. } \\
\text { Center of technology for the } \\
\text { development of new concepts. }\end{array}$ & $\begin{array}{l}\text { Development of new processes via } \\
\text { engineering and } \mathrm{P} \& \mathrm{D} \text { centers. } \\
\text { Center of innovation and reference in } \\
\text { project management. }\end{array}$ & $\begin{array}{l}\text { Complete development of new } \\
\text { products and systems through } \\
\text { P\&D. }\end{array}$ & $\begin{array}{l}\text { Complete development of new } \\
\text { equipment and systems } \\
\text { through P\&D. }\end{array}$ \\
\hline
\end{tabular}

Source: adapted from Figueiredo (2003) 


\section{DESIGN AND METHOD OF STUDY}

With the aim of classifying the present research, it was adopted as reference the taxonomy presented by Vergara (2003), which proposes two basic standards: as for the ends and means. As for the ends, the research is descriptive. Descriptive, because it aims to know and interpret the reality without interfering in it to interpret it (Churchill, 1987). As for the means, the research is participative, of field and documental. Participative in the moments that there was constant interaction between interviewer/interviewed and of the entire problem involved persons under investigation. Field research, because it collected primary data of the organization in question.

The research was developed from a pure case study, according to Yin (2005) making possible an investigation preserving the holistically and significant characteristics of the events, such as life cycles, organizational and managing processes. Besides, it was also used documental investigation, because enterprise internal documents, related to the object in study, not available to public consulting, and was analyzed.

\section{SYNTHESIS OF SUDAMÉRICA KNAPP TECHNOLOGICAL COMPETENCES ACCUMULATION DURING THE PERIOD OF 1998 AND 2005}

The branch office accumulated technology competence with different averages (in years) to the researched period in activities of engineering and projects management, in the organization processes and fittings control, in activities related to products and equipments. Although the activities are interlinked and interdependent, it was observed in the study a different accumulation speed. All the researched activities were, in 1998, in the basic level, the functions related to engineering and projects management was the one that first began to develop innovative activities, in the beginning of 2002 and the functions related to equipments kept of developing routine activities till the end of the researched period.

Graphic 1 presents the period in years that it took the enterprise to acquire and accumulate technological competence in activities related to engineering and projects management, taking about 3 years to start the development of innovative activities, getting to pre-intermediate level in 2002 and reaching intermediate level (level 5) from 2004 with the development of innovative solutions in its projects with the applying of engineering concepts by means of laboratory tests and performance simulations and the prototype construction to validate created solutions. 


\section{Graphic 1: Technological Competence Accumulation - Engineering and Project Manager Activities}

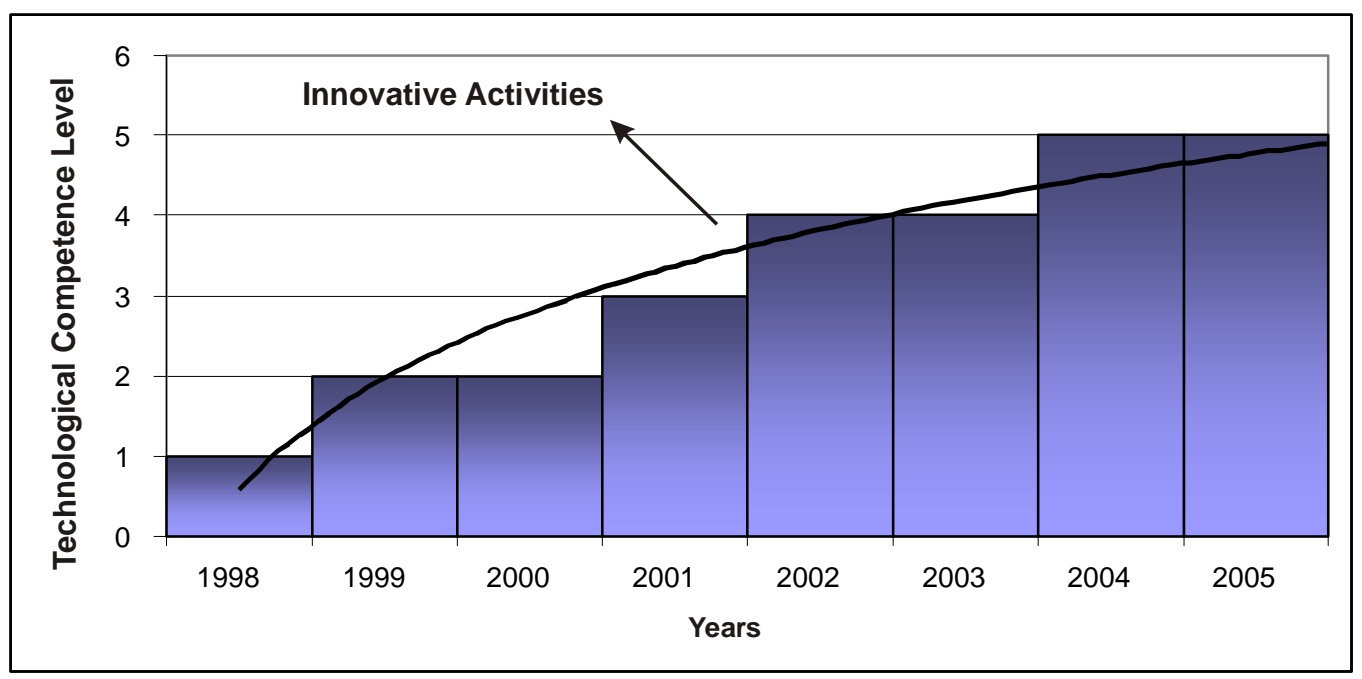

This activity was the one that reached level 4 in the least time due to the strong interaction between the technological head office and the branch one, mainly by the good functioning of the interchange mechanism among professionals and by the optimum functioning of the group formalization mechanism to discuss and analyze critically of engineering projects constituting an important factor to the creation of knowledge critical mass to the receiver branch of the technology in transference process.

Graphic 2 presents the period in years it took the enterprise to acquire and accumulate technological competence in activities related to the organization processes and installations control taking about 6 years to start the developments in innovative activities reaching the pre-intermediate level (level 4) from 2004, keeping on this stage till the end of 2005.

\section{Graphic 2: Technological Competence Accumulation - Organization Processes and Installations Control Activities}

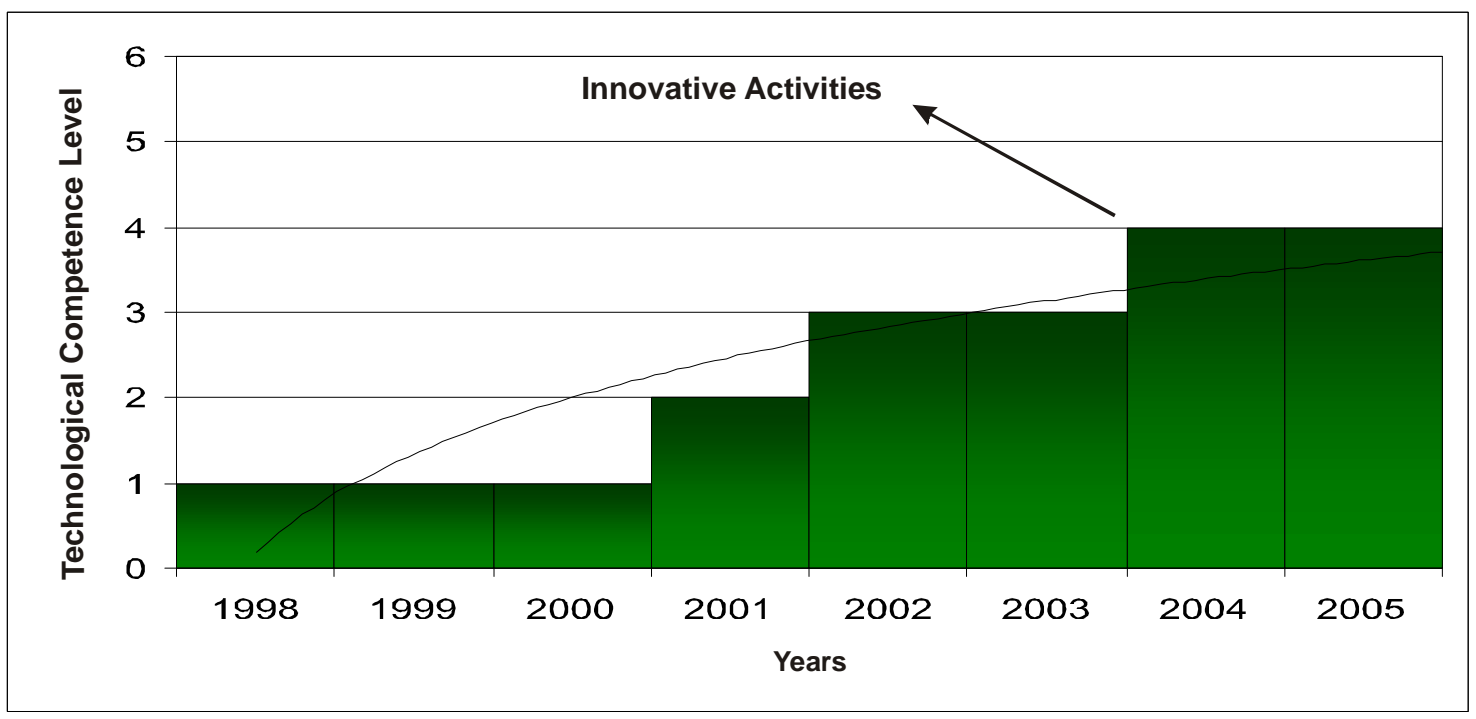

These processes reached an optimum operational and technical level acting as facilitator in the development of activities related to engineering and projects management, allowing an increasing in 
data and information flux among the areas, creating an internal favorable environment to the dissemination and socializing of knowledge in the branch office.

Graphic 3 presents the period in years it took the enterprise to acquire and accumulate technological competence in activities related to products. In the starting absorption phase, the branch office acted as the head office furnisher in replication the products based on the Brazilian inner market demand, guaranteeing the maintenance of technical specifications and performing routine inspections sending and receiving goods, not exceeding the basic competence level (level 1). With the beginning of the technology transference project the focus of the enterprise changed from a simple replicator to a Brazil manufactured component and mechanical elements furnisher, with the cooperation of a technological partner developed and homologated by the head office, falling on the branch office the control and final validation of the product, this way it was possible, in 6 years, to reach the first stage of innovative capability, pre-intermediate level (level 4) finishing the studied period developing activities in intermediate level (level 5).

\section{Graphic 3: Technological Competence Accumulation - Products Activities}

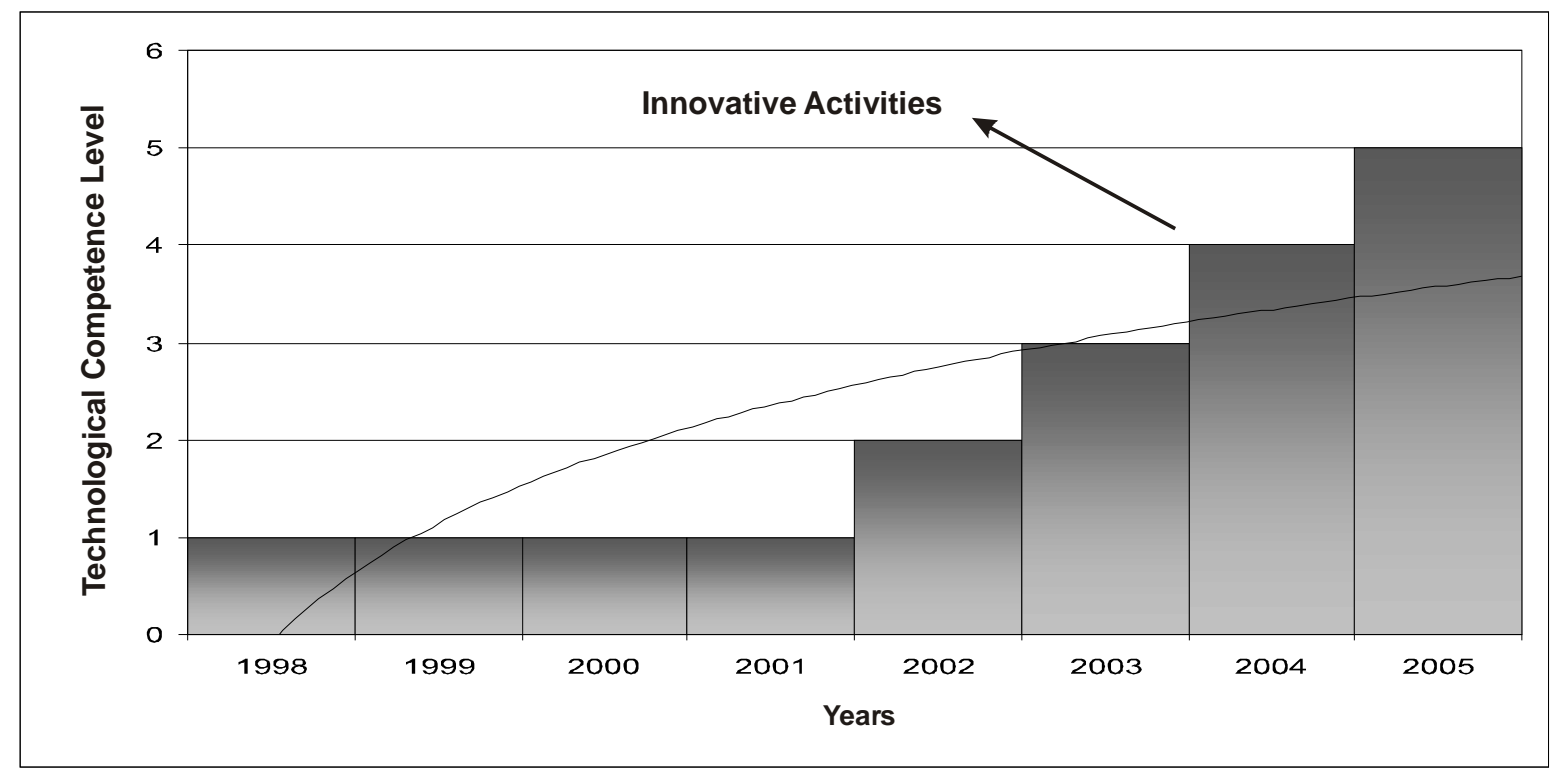

Graphic 4 presents the period in years it took the enterprise to acquire and accumulate technological competence in activities related to equipments. In the initial absorption phase, the branch office acted as a head office furnisher in replication equipments an so it kept in basic competence level (level 1) accomplishing routine competences as for instance, technical inspections to guarantee acquired equipment specification. In the phase it comprehended the technological transference project period, the branch office has not developed innovative activities, reaching extra-basic level (level 3) going on acting in routing activities accomplishing small adaptations in equipment projects to comply with the basic needs of operation for its clients. 


\section{Graphic 4: Technological Competence Accumulation - Activities Related to Equipments}

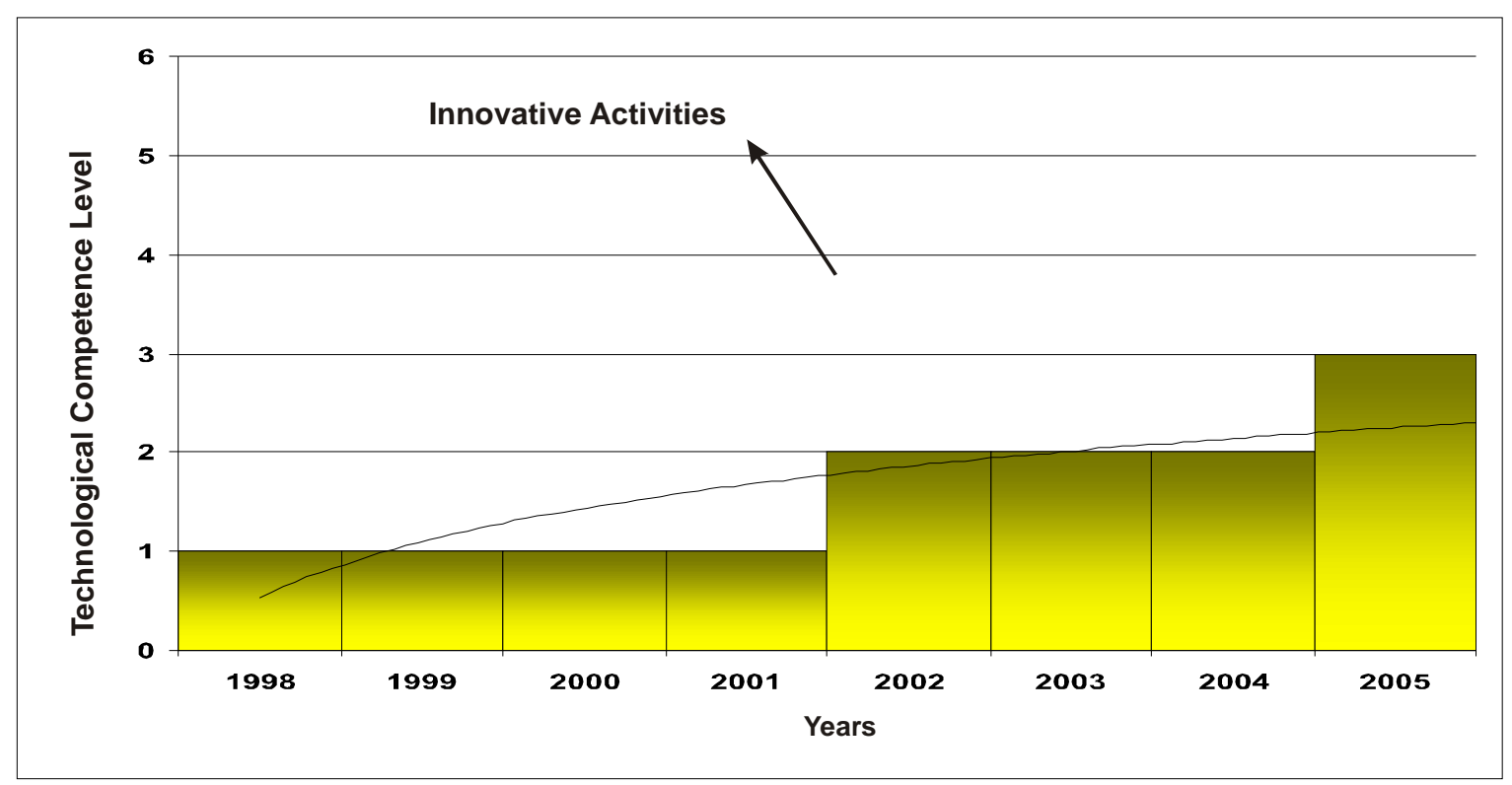

Based on the graphics 1, 2, 3 and 4 analysis, it is observed that the branch office accumulated technological capability with different rates to each studied activity. It took the enterprise 4 years to accumulate innovative competencies in engineering and projects management activities, while to accumulate innovative competences in activities related to organization and fitting control processes it needed 06 years, the same time spent to the innovative competences accumulation to the activities related to products. It was verified that the enterprise has not accumulated innovative competences to equipments function, getting on developing routine activities.

Graphic 5 illustrates the situation described on the above paragraph, presenting the comparative way the 4 activities researched in the branch office. The graphic lines show an accumulation tendency in the technological competences through time from the usage of a logarithmic function.

It is emphasized that the branch office, despite having absorbed a new technology by the transference process, has not reached advanced level of technological competence in neither function nor developed activity keeping on intermediate level till the end of the researched period. 


\section{Graphic 5: Accumulation Tendency in the Technological Competences through Time from the Usage of a Logarithmic Function}

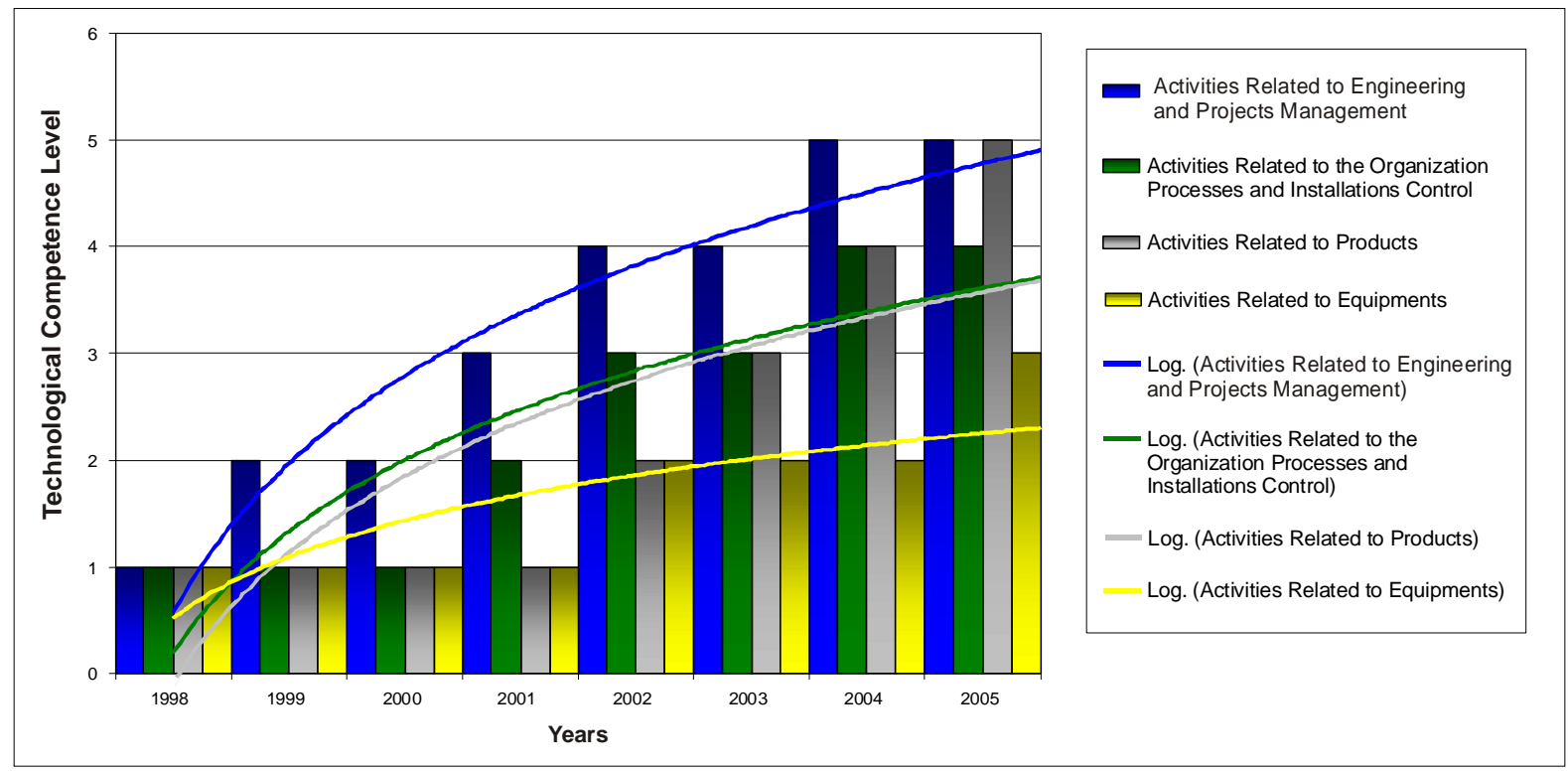

It has been observed in this study that the previous studies confirmation as for Bell and Pavitt (1995), Figueiredo (2003), Ferigotti (2002) that evidence the importance of planning and organizational systems structuring to the technological capability accumulation and to the development or innovative activities. The work group making up in projects management, the information flux increasing, computing systems implanting, training, practical applying of techniques by means of simulations and prototype building up seems to have influenced, in a positive way, the technological competences accumulation.

The competences accumulation trajectory, mainly, from 2002 to 2005 (Graphic 5), was the result of an integrated knowledge applied in technological activities developed by the branch office. The integration is the association that, in fact, the enterprises can find to explore synergistically, by means of the specialized and placed in different divisions knowledge base (Leonard-Barton, 1995). This integrated development contributed, as seen, to significant technological competences accumulation allowing that in only 3 years the branch office started to develop innovative activities to the engineering and projects management.

\section{CONSIDERATIONS}

This article aimed to evaluate and analyze head office and branch office technological competence accumulation, and, so, studied the technology transference process of Knapp Sudaméria enterprise during the interval of the transference process previous period (1998-2001) and the transference process accomplishment period (2002-2005).

The work searched for previous studies as Ariffin (2000), Figueiredo (2003) and Ferigotti (2002), to evaluate the accumulation by means of different functions or technological activities developed by the studied enterprise. However, the study differed from the other ones for searching to measure this phenomenon by means of a case study involving technology transference process between technological head office and branch office, identifying strategy and mechanism adopted for the effectiveness of this process. 
So, the study allowed identifying that the technology transference mechanisms agreed between head office and receiver were the licensing contract and the sub-contracting of furnishers to the components and equipments part production. Based on the theoretical reference used to identify these mechanisms, it was concluded that although Saad (2000) supports that licensing can impact directly in the necessary time to technology absorption, depending on local policies, involving high cost and, in some cases, making it difficult to develop competences, to the researched case these elements do not represent barriers or difficulties to the technological competences accumulation neither even less to the technology transference process accomplishment that was accomplished within the term established by the chronogram, following this project budget, not being influenced or impacted by governmental policies that represented loss to the receiver branch office.

The technology transference mechanism classified as sub-contracting was the way used that best adequate to the developed transference process, because it made possible by means of an specific contract, the manufacturing of part of the equipments, products and elements without the need of investing significantly in structuring the branch office, because these materials presented a low aggregated value and did not involve accumulation of a representative knowledge to the branch office.

The branch office developed technological activities and engineering functions and projects management, organization processes and fittings control, products and equipments and according to the research accomplished the enterprise was in level 1 acting in routine tasks in 1998 and reached, in 2002 , the pre-intermediate level starting to develop innovative activities to the engineer function and projects management. The pre intermediate level, first step in the innovative activities development, was not reached by the equipment function and was reached by the processes functions of organization and fittings and products control from 2004. It is detached that the branch office did not get to develop activities in advanced level.

The main barriers identified were related to cultural differences that made the foreign knowledge access difficult. The most significant difficulty was the German language understanding that caused, in some situations, obstacles, fails and deficiencies in communication among the technology transference process involved persons. It was verified that the exchange oscillation (Real x Euro) and the excessive tributary load applied in the country, also generated difficulties to the process effectiveness.

The knowledge creation and development was conditioned and depended on technology importing from the technological head office, however the technological competence accumulation was possible thanks to some identified factors as: pro-active position and professional qualification of the process involved personnel, besides planning and structure of the transference process previous phase (19982002) making it possible the necessary absorption to the process effectiveness.

The established partnership favored the professional personnel importing from the head office and the developing of processes and mechanisms of socializing allowing the branch office to convert the learning of individual level to the organizational one. Theses mechanisms did not happen in isolated way and were made potential with capable national professionals contracting allied to continuous efforts of standardizing and projects codifying and the search for shared solutions to problems by means of meetings to critical analysis.

It is suggested that studies being accomplished aiming to analyze and measure the influence of the mechanism and strategy to the promotion of technology transference process with the technological competence accumulation; studies of comparative cases in enterprises the act in the same area or segment that passed through the technology transference process head-branch office. Evaluating the speed or time to technological competence accumulation, studies that evaluate the cultures, structure, outer and inner environment and resources influence to the technological competence accumulation in enterprises that passed through technology transference process, studies that evaluated the influence of outer factor as: government policy, macroeconomics, environmental and industrial to the technological competence accumulations in enterprises that search for acquiring technology by means of the transference process. 


\section{REFERENCES}

Ariffin, N. (2000). The internationalization of innovative capabilities: the Malaysian electronics industry. Thesis. Brighton, Science and Technology Policy Research (SPRU), University of Sussex.

Ariffin, N., \& Figueiredo, P. N. (2003). Internacionalização de capacidades tecnológicas: implicações para estratégias governamentais e empresariais de inovação e competitividade da indústria eletrônica no Brasil. Rio de Janeiro: FGV.

Bell, M., \& Pavitt, K. (1993). Accumulating technological capability in developing countries. Proceedings of the World Bank Annual Conference on Development Economics, Washington, DC.

Bell, M., \& Pavitt, K. (1995).The development of technological capabilities. In I. Haque (Ed.). Trade, technology and international competitiveness. Washington, DC: World Bank.

Churchill, G. A., Jr. (1987). Marketing research: methodological foundations. Chicago: The Dryden Press.

Katz, J. (1995). Domestic technology generation in less developed countries: a review of research findings (Report). Buenos Aires, Argentina, IDB/ECLA Research Program in Science and Technology.

Ferigotti, C. M. S. (2002). Acumulação de competência tecnológica em processos e produtos e aprendizagem tecnológica: o caso Eletrolux S/A - Unidade de Guabirotuba - Curitiba/PR. Dissertação de Mestrado. Fundação Getúlio Vargas, Rio de Janeiro, RJ, Brasil.

Figueiredo, P. N. (2003). Aprendizagem tecnológica e performance competitiva. Rio de Janeiro: FGV Editora.

Gibbons, M., Limoges, C., Nowotny, H., Schwartzman, S., Scott, P., \& Trow, M. (1994). The new production of knowledge. London: Sage Publications.

Leonard-Barton, D. (1995). Nascentes do saber: criando e sustentando as fontes de inovação. São Paulo: Editora FGV.

Organisation for Economic Co-Operation and Development. (1994). Frascati Manual 1993: the measurement of scientific and technological activities: proposed standard practice for surveys of research and experimental surveys of research and experimental (5th ed.). Paris: Author.

Pavitt, K. (1985). Technology transfer among the industrially advanced countries: international technology transfer: concepts, measures and comparisons. New York: Praeger Scientific Press.

Pavitt, K. (1998). Technologies, products and organization in the innovating firm: what Adam Smith tells us and Joseph Schumpeter doesn't. Industrial and Corporate Change, 7(3), 433-51.

Rothwell, R., \& Dodgson, M. (1991). External linkages and innovation in small and medium-sized enterprises. $R \&$ D Management, 21(2), 125-137.

Saad, M. (2000). Development through technology transfer. Bristol, GRB: Intellect Books.

United Nations Industrial Development Organization. (2002). Industrial development report 2002/2003: competing through innovation and learning (Report). Vienna, Austria: Author. 
Vergara, S. C. (2003). Projetos e relatórios de pesquisa em administração. São Paulo: Atlas.

Yin, R. K. (2005). Estudo de caso: planejamento e métodos. Porto Alegre: Bookman. 